pez é integrada por Ana Maria Paulino, Sylvie C. Josserand, Lourival Santos, João Francisco F. Gonçalves, Diana Mindlin e Sérgio Gregório.

\title{
Cursos:
}

Participando em cursos de Especialização e de Pós-graduação sobre Arquivologia ou Organização de Fontes Documentais, a Prof. Dra. Heloísa Liberalli Bellotto colaborou, ao longo do ano, com várias Universidades Federais: em Itabuna/BA, Fluminense - Niterói, Amazonas, Acre, Belém do Pará, São Carlos, em S.Paulo e na Faculdade de Arquitetura e Urbanismo da USP, sobre Patrimônio Cultural; ao lado da Profa. Dra. Yêdda Dias Lima, na Escola de Arte e Comunicaçōes USP no Curso de Especialização sobre Organização de Arquivos.

\section{Assessoria técnica:}

Para assessorar na elaboração do Catálogo de Obras Raras do Museu Emílio Goeldi, de Belém do Pará, foi convidada por aquela entidade Rosemarie E. Horch, especialista no assunto.

A convite da Fundação Cultural da Prefeitura de Orleans, SC, a Profa. Dra. Heloísa Liberalli Bellotto acompanhou a organização de documentos históricos da Cia. de Colonização Grão-Pará. Estes documentos pertencem à antiga Cia. de Colonização e Imigração Grão-Pará.

\section{Exposiçōes:}

Freqüentemente o IEB é solicitado por entidades nacionais e estrangeiras a participar de eventos culturais, não só através da pesquisa como também de seu acervo. Em fins do ano passado, por ex., o Museu de Artes do Rio Grande do Sul - MARGS, realizou em Porto Alegre/RS, a mostra "Caminhos do Desenho Brasileiro" e para a qual seguiram desenhos e aquarelas de Cícero Dias, Tarsila do Amaral, Anita Malfatti, Brecheret, Haarberg, Manuel Bandeira, Rosário Fusco, Guignard, Pedro Nava, Voltolino, Antônio Moya e Mário de Andrade, num total de 25 (vinte e cinco) obras que ficaram expostas na denominada "Sala Destaque".

Integrando-se às homenagens prestadas a Heitor Villa-Lobos, o IEB realizou em março deste ano uma exposição comemorativa do Centenário de Nascimento do grande músico brasileiro. Para tanto, além de ampliações fotográficas, foram utilizadas ediçōes raras contemporâneas ao compositor, partituras, discos, recortes, programas musicais e vários documentos originais que pertenceram a Mário de Andrade hoje na Biblioteca e no Arquivo do Instituto. Complementaram a mos- 
tra, ediçōes atuais publicadas sobre a vida e a obra do compositor e maestro.

Através de cópias, pelo sistema xerox, a exposição foi cedida, por empréstimo ao Instituto de Artes do Planalto da Universidade Estadual Paulista "Júlio de Mesquita Filho", para integrar a Semana Villa-Lobos, durante o mês de julho.

Como parte do Projeto Brasil-França, patrocinado pelo Ministério de Relações Exteriores e do Ministério da Cultura, o Instituto de Estudos Brasileiros, se fez presente no evento através da exposição "João Guimarães Rosa - Vie et création" sob a coordenação da Profa. Dra. Cecilia de Lara. A mostra realizou-se em abril deste ano em Paris, na Maison de L'Amérique Latine e contou com a presença de várias autoridades brasileiras.A exposição permanecerá na França até dezembro do corrente, devendo ser apresentada em várias universidades francesas.

Fazendo parte do mesmo Projeto Brasil-França, o IEB deverá enviar para Paris neste segundo semestre, o quadro Retrato de Mário de Andrade, óleo de Lasar Segall datado de 1927 que integrará a mostra sobre o Modernismo.

A convite da Fundação Bienal de São Paulo o IEB se fará representar na XIX Bienal Internacional de São Paulo deste ano - mostra "Imaginários Singulares" - através de desenhos de Tarsila e um guache de Ismael Nery, num total de oito peças da Col. Mário de Andrade.

Transcorrendo a 9 de outubro os 94 anos de nascimento de Mário de Andrade, o Setor de Artes Visuais do IEB programou uma exposiçāo dos desenhos realizados pelo escritor paulista, pertencentes à Coleção que leva seu nome.

\section{Visitas:}

No início do ano, o IEB recebeu a visita do Reitor da Universidade de São Paulo Prof. Dr. José Goldemberg. Para a ocasião foi organizada uma amostragem representativa do acervo do Instituto bem como das realizaçōes e pesquisas dos vários setores.

Em fevereiro deste ano, visitou o IEB o Ministro da Cultura Prof. Dr. Celso Furtado que se fez acompanhar de especialistas e autoridades ligadas ao SPHAN. O ministro conheceu e tomou contato com o Acervo do Instituto sobre o qual ficou especialmente impressionado. Para a oportunidade organizou-se uma pequena mostra das raridades biblio- 